\title{
Plasmids Determining I Pili Constitute a Compatibility Complex
}

\author{
By R. W. HEDGES AND NAOMI DATTA \\ Department of Bacteriology, Royal Postgraduate Medical School, \\ Hammersmith Hospital, Du Cane Road, London, WI 2 oHS
}

(Received 4 January 1973)

SUMMARY

\begin{abstract}
Plasmids which determine I pili were subdivided by their compatibility properties. The original examples, R64, RI44 and Col Ib-P9, together with others more recently isolated, constituted one group, termed $\mathbf{I} \alpha$. Another group, I $\beta$, was compatible with $\mathrm{I} \alpha$ plasmids. The $\mathrm{I} \beta$ group was represented by some newly observed trimethoprim-resistance factors. A group incompatible with both of these (possibly the ancestral form) was designated $\mathbf{I} \omega$. Yet another group, designated $I \gamma$ was compatible with all the above plasmids, and with members of all other known compatibility groups. Its exemplar repressed piliation by some, but not all, mutant $\mathbf{l} \alpha$ plasmids derepressed for pilus synthesis. Exclusion was not necessarily correlated with incompatibility.
\end{abstract}

\section{INTRODUCTION}

Colicin factor Col Ib-P9 and certain $f_{i-}^{-} \mathrm{R}$ factors (e.g. R64, R 144) are self-transmissible and determine the production of sex pili (I pili) which are related by serological and phageadsorption criteria (Meynell \& Datta, 1967; Meynell \& Lawn, 1967; Meynell \& Lawn, 1968). R factors R64 and Ri44 are incompatible with one another and with Col Ib-P9. They thus belong to a single compatibility group, I (Datta \& Hedges, I97I).

In early work on classification of $\mathrm{R}$ factors, it was shown that in a high proportion of cases, transfer to Escherichia coli $\mathrm{KI} 2$ of antibiotic resistance from wild-type strains of Salmonella and Escherichia coli was associated with acquisition of I pili (Lawn, Meynell, Meynell \& Datta, 1967; Meynell \& Datta, 1969).

Anderson (1968) showed that strains of Salmonella carried resistance plasmids which were non-self-transmissible and also separate transfer (or sex) factors which brought about their transfer. Some of these sex factors (e.g. that termed $\triangle$ ) determined I pili (Anderson, 1968). Many of the $\mathrm{R}$ factors found by Lawn et al. (1967) to be associated with I pilus production seem to be aggregates of the sort described by Anderson (I968), since their resistances can co-exist with the prototypic I group plasmids. I group R factors, previously reported (Meynell \& Datta, I969) as the most abundant of the $f^{-}$class, are thus rather rare.

This paper describes the relationships between plasmids which determine I pili using exclusion and compatibility as our criteria.

\section{METHODS}

Bacteria. All experiments were carried out using nutritionally distinct strains of Escherichia coli KI2.

Plasmids. Plasmids determining I pili are listed in Table I.

Phages. If I (Meynell \& Lawn, I968); PI (Lennox, I955). 


\section{Table I. Plasmids determining I pili}

\begin{tabular}{|c|c|c|c|}
\hline Plasmid & $\begin{array}{c}\text { Resistance* and } \\
\text { colicine } \\
\text { determinants }\end{array}$ & Pilus production & Reference \\
\hline R64 & ST & Repressed & Meynell \& Datta (1967) \\
\hline Ri 44 & TK Col Ib & Repressed & Meynell \& Datta (1967) \\
\hline RI44drd3a† & Col Ib & Derepressed & \\
\hline $\mathrm{R} 648^{* * *}$ & ASK & Repressed & \\
\hline Col Ia-CA 53 & Col Ia & Repressed & Lawn et al. (1967) \\
\hline Sex factor $1-16 d r d$ & & Derepressed & Meynell (1968) \\
\hline R483 & STp & Repressed & Hedges, Datta \& Fleming (1972) \\
\hline JR66a & SK & Repressed & Datta \& Hedges (1973). \\
\hline R62 Iat & $\mathrm{T}$ & Repressed & \\
\hline
\end{tabular}

* Drug resistance markers abbreviated as follows: S, streptomycin; $\mathrm{T}$, tetracycline; A, ampicillin; $\mathrm{K}$, kanamycin; $\mathrm{Tp}$, trimethoprim.

+ Ri44drd3a a spontaneous segregant of Ri44drd3 (Meynell \& Datta, 1967) from which antibiotic resistance was lost.

** R factor derived from a strain of Salmonella typhimurium supplied by Mr W. J. Sojka.

$+\mathrm{R}$ factors derived from strains of Salmonella typhimurium supplied by Professor J. N. Coetzee.

Media. These were as described by Datta, Hedges, Shaw, Sykes \& Richmond (1971). Transfer of $R$ factors. Methods were as described by Datta et al. (1971).

Compatibility of $R$ factors and transfer from doubles. Methods were as described by Coetzee, Datta \& Hedges (1972).

Recognition of I pili. (i) Constitutive production of I pili was recognized if lysis was visible when an undiluted preparation of If I (approx. $10^{11}$ plaque-forming units $/ \mathrm{ml}$ ) was spotted on cultures spread on nutrient agar plates. (ii) Repressed production of I pili was recognized by an increase in titre of phage If $I$ in the culture under test. The method was as described by Datta et al. (1971).

PI transduction was as described by Jacob (1955), selection being for antibiotic resistance.

\section{RESULTS}

\section{Identification of $R$ factors determining $I$ pili}

In strains of bacteria which possess transferable drug-resistance determinants and produce I pili, the genes for resistance and pili may be carried on a single plasmid, or the pilus genes may be carried by a sex factor separate from the drug-resistance plasmid (Anderson, 1968). The plasmids which we investigated were of the former kind. Evidence for this is as follows.

Ri44 and R64 have been shown by physical methods to be single circular molecules (Falkow, Tompkins, Silver, Guerry \& Le Blanc, 197I ; Falkow, personal communication; Vapnek, Lipman \& Rupp, I97I). R62ra was transduced by phage PI between strains of Escherichia coli KI2. Transduced R621a was transmissible and determined I pili. After co-existence with I plasmids R648 or JR66a, R62 I a still determined tetracycline resistance and I pili.

The evidence that JR66a and R483 were plasmids in which determinants for I pili were carried on the same molecule as drug resistance rests on their compatibility properties (Datta \& Hedges, I973, and Table 2). In addition, R483, after co-existence with R I44, retained streptomycin and trimethoprin resistances and still determined I pili. Col Ia-CA53 produces I pili (Lawn et al. 1967) and its incompatibility withR64 and R I 44 indicates that its colicin gene is carried on the same molecule as the I pilus genes. 
Table 2. Exclusion and compatibility relationships of plasmids determining I pili

\begin{tabular}{|c|c|c|c|}
\hline $\mathrm{R}$ factor & $\begin{array}{c}\text { Transfer to } \\
\text { host carrying }\end{array}$ & $\begin{array}{l}\text { Frequency/ } \\
\text { donor cell }\end{array}$ & Characters of purified transipients \\
\hline R64 & $\begin{array}{l}\text { RI } 44 \\
\text { R648 } \\
\text { Col Ia } \\
\text { R483 } \\
\text { JR66a } \\
\text { R62Ia }\end{array}$ & $\begin{array}{l}1 \times 10^{-3} \\
2 \times 10^{-7} \\
1 \times 10^{-3} \\
1 \times 10^{-5} \\
1 \times 10^{-3} \\
5 \times 10^{5} \\
\text { Not testable: }\end{array}$ & $\begin{array}{l}\text { 2/2 R64 only } \\
\text { 20/20 R64 only } \\
\text { 20/20 R64 only } \\
\text { 20/20 both plasmids* } \\
\text { 19/20 R64 only: I/20 recombinant }+ \\
\end{array}$ \\
\hline Ri44 & $\begin{array}{l}- \\
\text { R64 } \\
\text { R648 } \\
\text { Col Ia } \\
\text { R483 } \\
\text { JR66a } \\
\text { R62ra }\end{array}$ & $\begin{array}{l}1 \times 10^{-3} \\
<10^{-7} \\
<10^{-7} \\
<10^{-7} \\
1 \times 10^{-3} \\
<10^{-7} \\
\text { Not testable }\end{array}$ & $\begin{array}{l}\text { No transfer observed } \\
\text { No transfer observed } \\
\text { No transfer observed } \\
20 / 20 \text { both plasmids* } \\
\text { No transfer observed } \\
\end{array}$ \\
\hline R648 & $\begin{array}{l}- \\
\text { R64 } \\
\text { RI } 44 \\
\text { Col Ia } \\
\text { R483 } \\
\text { JR66a } \\
\text { R62 Ia }\end{array}$ & $\begin{array}{l}1 \times 10^{-3} \\
1 \times 10^{4} \\
<10^{-7} \\
5 \times 10^{-5} \\
6 \times 10^{-4} \\
\text { Not testable } \\
5 \times 10^{-15}\end{array}$ & $\begin{array}{l}\text { 20/20 R648 only } \\
\text { No transfer observed } \\
20 / 20 \text { R } 648 \text { only } \\
\text { I0/20 both plasmids*: } 2 / 20 \text { R648 only } \\
\text { 10/20 both plasmids*: } 10 / 20 \text { R648 only }\end{array}$ \\
\hline $\mathrm{R} 483$ & $\begin{array}{l}- \\
\text { R64 } \\
\text { RI } 44 \\
\text { R648 } \\
\text { Col Ia } \\
\text { JR66a } \\
\text { R62Ia }\end{array}$ & $\begin{array}{l}2 \times 10^{-3} \\
1 \times 10^{-3} \\
1 \times 10^{-3} \\
1 \times 10^{3} \\
2 \times 10^{-3} \\
1 \times 10^{-3} \\
1 \times 10^{-3}\end{array}$ & $\begin{array}{l}\text { 20/20 both plasmids, but unstable } \$ \\
20 / 20 \text { both plasmids, but unstable } \S \\
20 / 20 \text { both plasmids, but unstable } \$ \\
\text { 20/20 both plasmids* } \\
5 / 20 \text { R483 only: } 15 / 20 \text { both present but } \\
\text { unstable } \$ \\
\text { 20/20 both plasmids* }\end{array}$ \\
\hline $\mathrm{JR} 66 \mathrm{a}$ & $\begin{array}{l}- \\
\text { R64 } \\
\text { Ri44 } \\
\text { R648 } \\
\text { R483 } \\
\text { Col Ia } \\
\text { R62 Ia }\end{array}$ & $\begin{array}{l}3 \times 10^{-3} \\
2 \times 10^{-4} \\
2 \times 10^{-7} \\
\text { Not testable } \\
2 \times 10^{-3} \\
<10^{7} \\
2 \times 10^{-3}\end{array}$ & $\begin{array}{l}\text { 20/20 JR66a only } \\
\text { 10/10 JR66a only } \\
8 / 20 \text { JR66a only: i2/20 } \mathrm{Tp}^{\mathrm{r}} \text { retained but } \\
\text { non-transmissible: } \\
\text { No transfer observed } \\
\text { 20/20 both plasmids* }\end{array}$ \\
\hline R62 Ia & $\begin{array}{l}\text { R64 } \\
\text { RI44 } \\
\text { R648 } \\
\text { Col Ia } \\
\text { R483 } \\
\text { JR66a }\end{array}$ & $\begin{array}{l}2 \times 10^{-3} \\
\text { Not testable } \\
\text { Not testable } \\
2 \times 10^{-5} \\
2 \times 10^{-1} \\
2 \times 10^{-3} \\
4 \times 10^{-1}\end{array}$ & $\begin{array}{l}\text { - } \\
\text { - } \\
18 / 20 \text { both plasmids } *: 2 / 20 \text { R62 I a only } \\
20 / 20 \text { both plasmids* } \\
20 / 20 \text { both plasmids* } \\
20 / 20 \text { both plasmids* }\end{array}$ \\
\hline
\end{tabular}

* Both plasmids: indicates that resistances of each were stably inherited and separately transmissible.

+ Recombinant: indicates that resistances of each were always transmissible together, whichever drug was used for selection.

$\dagger$ Not testable: overlap of markers prevents recognition of double.

$\$$ Unstable: symmetrical loss of plasmids observed in drug-free medium.

See text. $T \mathrm{p}^{\mathrm{r}}$ indicates trimethoprim-resistance. 


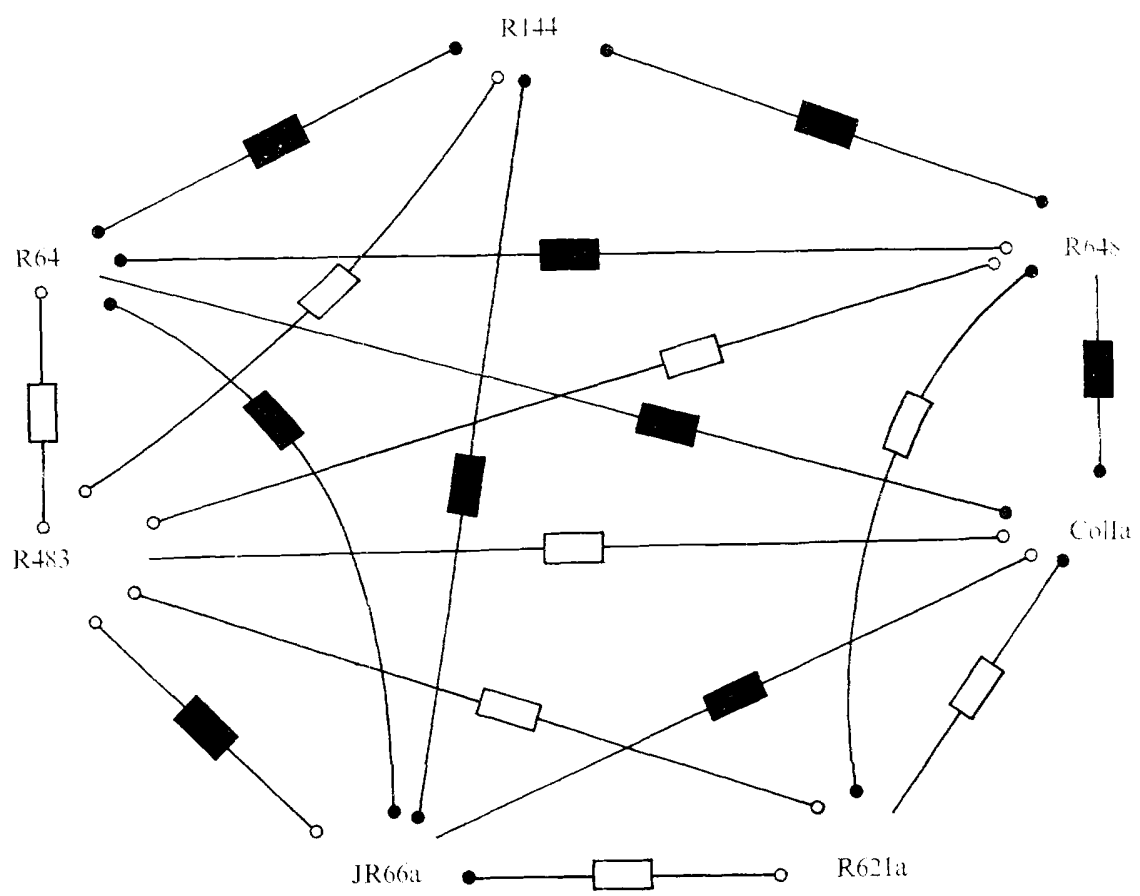

Fig. I. Relationships between plasmids determining I pili as shown in Table 2. - between plasmids indicates compatibility. - - - between plasmids indicates incompatibility. - - indicates exclusion, $-\mathrm{O}$ indicates lack of exclusion, by the plasmid beside which the symbol appears.

\section{Exclusion}

When R64 was mated with strains carrying R144 (with which it is incompatible; see below), the rate of transfer was reduced so drastically that only rarely were any transcipients observed. On the other hand, transfer of R64 to a recipient carrying the similarly incompatible $\mathrm{R} 648$ was as efficient as to an $\mathrm{R}^{-}$recipient. Thus in crosses between incompatible plasmids, exclusion was sometimes very efficient and sometimes absent.

In matings between strains carrying compatible pairs of $\mathrm{R}$ factors, exclusion was sometimes but not always observed, e.g. R62 Ia excluded R648 (and vice versa) but R62 Ia did not exclude (and was not excluded by) R483. Results are presented in Table 2 and Fig. I.

\section{Compatibility}

Among $\mathrm{R}$ factors determining I pili, four patterns of compatibility were distinguished. R64, Ri44, R648 and Col Ia were incompatible with one another. These we call typical I group plasmids or I $\alpha$. R483 was compatible with the I $\alpha$ plasmids and is designated I $\beta$. In crosses in which an $\mathrm{I} \alpha$ plasmid was introduced into an $\mathrm{R} 483^{+}$strain, the doubles were stable. But when R483 was transferred into a strain carrying R64, Ri 44 or R648 the resulting doubles were unstable, segregating clones carrying one or other plasmid (Table 2). The stability or instability of doubles depended upon which was the resident and which the newly introduced plasmid, and was independent of the host strain of Escherichia coli KI 2. Col Ia differed from the other I $\alpha$ plasmids in co-existing stably with introduced R483. JR66a was incompatible with plasmids of both $\mathrm{I} \alpha$ and $\mathrm{I} \beta$ groups and we propose the designation $\mathrm{I} \omega$. When one $\mathrm{I} \alpha$ plasmid was transferred into a strain already carrying an I $\alpha$ plasmid, incom- 
patibility was expressed so rapidly that doubles, even unstable, were never observed. The same was true in matings between $I \alpha$ and $I^{\prime \prime}$ : strains. But in matings between $\mathrm{R}_{4} 8_{3}(\mathrm{I} / \mathrm{\beta})$ and JR66a $(\mathrm{I} \omega)$ the results were more complicated. When R483 was transferred to a JR66a strain, a proportion of the trimethoprim-resistant transcipients retained JR66a; all (15/15) of these strains were unstable. From overnight broth cultures, a majority of clones carried one or other plasmid but not both. When JR66a was transferred to an R483 strain, a proportion of the kanamycin-resistant transcipients retained trimethoprim resistance, but in this case trimethoprim resistance was stable but non-transmissible (Datta \& Hedges, 1973).

R62 Ia was compatible with $\mathrm{I} \alpha, \mathrm{I} \beta$ and $\mathrm{I}(1)$ plasmids. This $\mathrm{R}$ factor was also compatible with plasmids of all other defined compatibility groups. (The only untestable group was Fiv whose only known member, RI24, confers tetracycline resistance only, as does R62ra itself.)

\section{Repression of I pilus synthesis}

Since R621a is compatible with all other I-pilus determining plasmids, we tested its ability to repress pilus production by mutant I plasmids which produce pili constitutively. R62Ia cannot be distinguished in the presence of $\mathrm{R}$ factors which determine tetracycline resistance, but was tested with Ri 44drd3a and the derepressed sex factor of Col Ib, I-I $6 d r d$ (Meynell, I968). Pilus production remained constitutive in 10 of ro independently isolated clones of the double $\mathrm{J}_{53}$ (RI44drd3a) (R62 Ia) but was repressed in Io of Io clones of J62 (I-I6 drd) (R62ra).

\section{DISCUSSION}

$\mathrm{R}$ factors and other transmissible plasmids of Gram-negative bacilli can be classified by compatibility in Escherichia coli KI2 (Datta \& Hedges, I97I) or by the specificity of their sex pili (Lawn et al. 1967). These criteria are correlated, in that any known plasmid determining F-like pili is compatible with any determining I pili (Meynell, Meynell \& Datta, 1968). However, numerous groups of plasmids have been identified which do not appear to determine either F-like or I pili and which are compatible with plasmids of either pilus type (e.g. the $\mathrm{N}$ and $\mathrm{P}$ compatibility groups [Datta \& Hedges, I97I; Datta et al. 197I]).

Plasmids determining F-like pili constitute several compatibility groups (Hedges \& Datta, I972). In this paper we show that plasmids determining I pili can also be subdivided by their compatibility properties.

To distinguish between I pili determined by $\mathrm{R}$ factors and I pili determined by a separate sex factor we used two techniques, Pr transduction and the construction of doubles with known I group plasmids. For example, R62 Ia, transduced by PI with selection for tetracycline resistance, still determined I pili. Secondly, when JR66a was transferred to an $\mathrm{R}_{62 \mathrm{Ia}}{ }^{+}$strain, each $\mathrm{R}$ factor was separately transferable from the double. R62Ia transcipients retained I piliation. Had the I pili been determined by a separate I group sex factor, it would have been eliminated by JR66a.

The classic I group factors, RI44 and R64, together with R648 and Col Ia-CA53 constitute the group we term $\mathbf{I} \alpha$. These exclude one another strongly and are incompatible. The incompatibility is so immediately expressed that even unstable doubles were never observed.

$\mathrm{R} 483$, which determines resistance to streptomycin and trimethoprim, is the prototype of the group which we designate $\mathrm{I} \beta$. When this $\mathrm{R}$ factor was first described, it was allocated to a new compatibility group, B (Hedges, Datta \& Fleming, 1972). We have subsequently shown that R483 determines I pili and is incompatible with JR66a (Datta \& Hedges, I973) 
and we withdraw therefore the designation $\mathrm{B}$ and substitute $\mathrm{I} \beta$. R483 does not exclude and is not excluded by any of the other I-pilus producing plasmids. It co-exists stably with plasmids of group I $\alpha$ (Hedges et al. I972) if an I $\alpha$ plasmid is introduced into a strain carrying resident $\mathrm{R} 483$. But when the cross was made in the other direction, $\mathrm{R} 483$ being transferred into a strain carrying R64, RI44 or R648, the transcipients were unstable doubles from which one or other plasmid was lost during growth in non-selective medium (Table 2). We are investigating the molecular basis of this phenomenon. Col Ia differed from the other $\mathrm{I} \alpha$ plasmids in forming stable doubles with $\mathrm{R} 483$, even when the latter was introduced into a col Ia+ strain (Table 2 ).

JR66a is incompatible with plasmids of groups $\mathrm{I} \alpha$ and $\mathrm{I} \beta$. The incompatibility with $\mathrm{I} \alpha$ plasmids was immediately expressed, but unstable doubles were observed with the I $\beta$ plasmid R483. We have termed the compatibility pattern of JR66a, I $\omega$, and postulated that this is the ancestral form from which $\mathrm{I} \alpha$ and $\mathrm{I} \beta$ have diverged (Datta \& Hedges, I973). JR66a excluded and was excluded by plasmids of group I $\alpha$, but markedly less efficiently than the intragroup exclusion by $\mathrm{I} \alpha$ plasmids.

R62 ra is an $f^{-}$plasmid determining tetracycline resistance and I pilus production. It is compatible with all plasmids tested, including members of all compatibility groups so far defined. In compatibility studies, R62 Ia showed no interaction (with one exception) with plasmids of groups $\mathbf{I} \alpha, \mathbf{I} \beta$ or $\mathbf{I} \omega$ and we have designated the group to which it belongs $\mathbf{I} \gamma$. The exception was dislodgement (Coetzee et al. 1972) of R62Ia by R648 and vice versa, i.e. introduction of one of these factors eliminated the other from some recipient clones, even though the two were compatible (Table 2 ). It was excluded by I $\alpha$ and I $\omega$ plasmids, but less efficiently than the intragroup $I \alpha$ exclusion.

Thus, among I pilus-determining plasmids there is not complete correlation between exclusion and incompatibility, for example, R62 Ia and R648 are compatible but exclude one another, whereas R483 and JR66a are incompatible yet do not exclude one another. It is on compatibility that we base our classification.

Since R62I a is compatible with the I $\alpha$ group, we can test whether it represses constitutive pilus synthesis by mutant plasmids of this group. R62Ia repressed pilus synthesis by the derepressed sex factor I-I $6 d r d$ but not that of R I $44 d r d 3 a$. We conclude that R62 Ia produces a transactive repressor capable of acting on the pilus synthesizing genes of I-I $6 d r d$ but not on those of Ri44drd3a.

Note: after this paper was submitted for publication, Grindley, Grindley \& Anderson ( I972) reported that two R factors, TPI I 4 and T- $\triangle d r p$ I, a laboratory construct, were mutually compatible although both determined I pili. The relationship of these two plasmids to the plasmids described in this paper has not been tested.

We thank Professor J. N. Coetzee (University of Pretoria) and Mr W. J. Sojka (Central Vererinary Laboratory, Weybridge, Surrey) for the strains of Salmonella typhimurium from which we isolated R62Ia and R648, Professor J. Konisky (University of Illinois) and Dr R. W. Moyer (Columbia University, New York) for strains of Escherichia coli carrying Col-Ia CA53 and Professor G. G. Meynell (University of Kent) for the sex factor I-I $6 d r d$.

\section{REFERENCES}

Anderson, E. S. (1968). The ecology of transferable drug resistance in the enterobacteria. Annual Review of Microbiology 22, 13 I-180.

Coetzee, J. N., Datta, N. \& Hedges, R. W. (1972). R factors from Proteus rettgeri. Journal of General Microbiology 72, 543-552.

Datta, N. \& Hedges, R. W. (I97I). Compatibility groups among $f^{-}$R factors. Nature, London 234, $222-223$. 
DatTA, N. \& Hedges, R. W. (I973). An I pilus-determining R factor with anomalous compatibility properties, mobilizing a gentamicin-resistance plasmid. Journal of General Microbiology (in the press).

Datta, N., Hedges, R. W., Shaw, E. J., Sykes, R. B. \& Richmond, M. H. (i97i). Properties of an R factor from Pseudomonas aeruginosa. Journal of Bacteriology 108, I244-1249.

Falkow, S., Tompkins, L. S., Silver, R. P., Gufrry, P. \& LE Blanc, D. (I97I). The replication of R-factor DNA in Escherichia coli $\mathrm{K} \mathrm{I} 2$ following conjugation. Annals of the New York Academy of Sciences $\mathbf{1 8 2}$, I $53-171$.

Grindley, N. D. E., Grindley, J. N. \& Anderson, E. S. (1972). R factor compatibility groups. Molecular and General Genetics II9, 287--297.

Hedges, R. W. \& DATTA, N. (1972). Ri24, an $f^{+1}$ R factor of a new compatibility class. Journal of General Microbiology 7r, 403-405.

Hedges, R. W., Datta, N. \& Fleming, M. P. (1972). R factors conferring resistance to trimethoprim but not sulphonamides. Journal of General Microbiology 72, 573-575.

$\mathrm{J}_{\mathrm{ACOB}}, \mathrm{F}$. (1955). Transduction of lysogeny in Escherichia coli. Virology $\mathbf{1}$, 207-220.

lawn, A. M., Meynell, E., Meynell, G. G. \& Datta, N. (1967). Sex pili and the classification of sex factors in the Enterobacteriaceae. Nature, London 216, 343-346.

Lennox, E. S. (1955). Transduction of linked genetic characters of the host by bacteriophage PI. Virology $\mathbf{x}$, $190-203$.

Meyneli, E. \& Datta, N. (1967). Mutant drug resistance factors of high transmissibility. Nature, London 214, $885-887$.

Meynell, E. \& Datta, N. (1969). Sex factor activity of drug resistance factors. In Bacterial Episomes \& Plasmids, pp. I20-133. CIBA Symposium, Edited by G. E. W. Wolstenholme and M. O'Connor. London: J. and A. Churchill.

Meynell, E., Meynell, G. G. \& Datta, N. (1968). Phylogenetic relationships of drug-resistance factors and other transmissible bacterial plasmids. Bacteriological Reviews 32, 55-83.

Meynell, G. G. (1968). Bacterial sex factors. Anmual Report of the Lister Institute for Preventive Medicine, London.

Meynell, G. G. \& LAWn, A. M. (1967). Sex pili and common pili in the conjugational transfer of colicin factor Ib by Salmonella typhimurium. Genetical Research 9, 359-367.

Meynell, G. G. \& Lawn, A. M. (I968). Filamentous phages specific for the I sex factor. Nature, London 217, I $184-1$ I 86.

Vapnek, D., Lipman, M. B. \& Rupp, W. D. (197I). Physical properties and mechanism of transfer of R factors in Escherichia coli. Journal of Bacteriology 108, 508-5I4. 